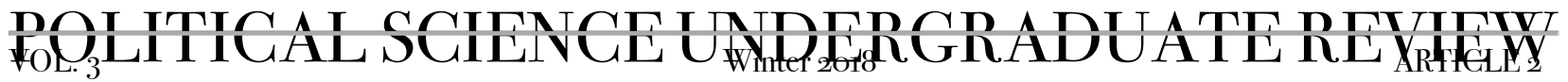

\section{China's Balancing Act: Examining China-DPRK Relations in an Era of Political Uncertainty}

\author{
By Matthew Boyd
}

\begin{abstract}
The current geopolitical situation in East Asia has existed in a precarious stasis since the armistice that ended the bloodshed of the Korean War. For the past 6o years, the Democratic People's Republic of Korea (DPRK) has been the biggest challenge to peace and security in Asia. Despite immense economic and political progress throughout East Asia through much of the late $20^{\text {th }}$ century, the DPRK has faced continued isolation and worsening economic fortunes. The regime in the DPRK has demonstrated that its primary goal is its own survival, and it is willing to pursue nuclear ambitions to serve this end. The question on the minds of many scholars and diplomats engaging with the question of East Asian security is whether or not the People's Republic of China can be expected to join the rest of the world in preventing an increasingly belligerent DPRK from obtaining the ability to deliver a nuclear payload. China has a long and complicated history with the Korean Peninsula and the DPRK, a history that demonstrates a duplicitous and practical approach to issues of Korean geopolitics. This paper will demonstrate the complicated relationship between China and the DPRK and demonstrate the ways in which China's complicated history with the peninsula has led to the current state of affairs. The paper will speculate as to the motivations of the Chinese government, and seek to understand China's actions on the international stage to both protect and condemn the DPRK's fragile political regime.
\end{abstract}

For over a generation, the international community has grappled with the question of what, if anything, can be done to bring peace to the Korean Peninsula. Since the hostilities of the Korean War were "frozen" in 1953, the Democratic People's Republic of Korea (DPRK), commonly referred to simply as North Korea, has continued to advance its nuclear and missile development programs. These advancements have come in spite of repeated international condemnations. Little progress has been made despite repeated attempts by the international community to curtail the state's aspirations of developing nuclear weapons that could strike the United States and anyone the DPRK views as hostile. The People's Republic of China is often viewed as the wildcard in analyses of the Korean issue, as it has both positioned itself as an historical ally of the DPRK, as well as a partner in the international community's efforts to sanction and curtail the nuclear ambitions of the North Korean regime. China is in a unique position in its relations with the DPRK, having been largely responsible for the survival of the regime during the Korean War. Since then, the relationship between the two states has been described as one of "lips and teeth" or "blood-cemented" brothers," in reference to the historical and political bond between the two countries, dating back to the 
early days of communism in Asia following the Second World War (Kim, 2OI7, pp. IO9-IIO). In recent years, however, this close bond between China and the DPRK has shown signs of weakness. Since the turn of $2 \mathrm{I}^{\mathrm{st}}$ century, the DPRK has continued to escalate its military standoff with its neighbours. As this standoff has increased tensions in the region dramatically, China has been shown to be much more reluctant to stand fully behind the regime than it once was. As this paper will demonstrate, Chinese foreign policy towards the DPRK has been shaped in large part due to the miracle of Chinese economic development and an immense focus on regional stability in the eyes of China's government. China has become much more willing to stand in line with the international community in order to limit the ability of the DPRK to produce nuclear weapons, while at the same time ensuring the economic wellbeing of the regime. China's national interests lie both in a stable Asia-Pacific, free of nuclear weapons, and the continued existence of the regime in some form in order to prevent an American-led reunification of the peninsula. China's policy toward the DPRK is characterized by a careful balance of economic engagement and political pressure. As Ohn remarks in his examination of the changing relationship between China and the DPRK, "China has worked to achieve the contradictory objectives of reinforcing the prospects of DPRK regime stability while preventing its nuclear program from developing into an international crisis" (Ohn, 20I5, pp. 484). Chinese policymakers have sought to protect Chinese interests to the greatest possible degree through a duplicitous set of foreign policy choices, in which the DPRK is stabilized economically to prevent collapse, while political pressures are consistently enforced in order to maintain relative geopolitical stability in the region. At the core of Chinese foreign policy toward the DPRK lies a deep desire of the government to protect Chinese national interests. China's interests in Northeast Asia primarily depend on maintaining stability, which is clearly reflected in their carefully balanced policy of both engaging and containing the government of the DPRK. This paper will analyze the origins of the China-DPRK relationship, and proceed to demonstrate the ways in which the Chinese government is enacting a policy of both engagement and constraint with the DPRK. The paper will further demonstrate that competing views of China's role in the Korean conflict serve to complicate matter unnecessarily, as any evaluation of China-DPRK relations must be based in fact and an understanding of each country's national geopolitical interests.

China has viewed Korea as an indispensable geopolitical necessity to ensure its own survival since as early as the Ming Dynasty. Jae Ho Chung remarks that China and Korea have always had a shared military and political history, finding themselves linked together through a geopolitical "curse" (Chung, 2OI3, pp. 245). Throughout history, Chinese kings fought countless wars and military campaigns against outside invaders to ensure continued Chinese influence over the Korean peninsula. From a military perspective, China has always viewed control over Korea to be critical in defending the Chinese homeland from invasion. As Chung explains in his history of China-Korea relations, "Korea is often compared to the 'dagger' pointed at the neck of China", owing to its geographical position as a vulnerable extension of the Chinese mainland out towards the Sea of Japan (pp. 245). In the modern era, the Korean War unequivocally demonstrated the critical importance that China placed on maintaining a degree of control over the divided Korean Peninsula (Chung, pp. 246). As the Chinese military would eventually enter the Korean War against UN troops directly, China had made a cost-benefit calculation and determined that ensuring the survival of the communist DPRK was in their national interests. This military decision paid off for China, as reunification of the peninsula under the American-backed South was averted.

Contemporary relations between China and the DPRK have thawed significantly since the end of the Korean War. This can be owed in large part due to political and economic rifts forming between the two 
countries, as China has seen significant reforms carry it to international power status. Conversely, the situation in the DPRK has not improved, as recurrent famine and financial hardship have left the country incredibly dependent on China as an economic lifeline and indispensable provider of financial aid (Ji, 2OOI, pp. 388). As China has transitioned into a system of state-run capitalism, leaders in China have looked upon the North Korean system with mounting disdain, and as Ji writes, "China regarded Kim's political slogans and governing principle of 'one for all and all for one' to be more Confucianist than Marxist", as he refers directly to the totalitarian principles of the DPRK's state ideology, "Juche" (Ji, 2OOI, pp. 390). The political cleavages that have developed between the two countries have continued to become exacerbated, as "Koreanised Marxism" and "Sinified Marxism" have found few ideological tenets in common, and the countries have taken different political and economic paths in the contemporary era (Ji, 2OOI, pp. 390). When it comes to economics, China's state capitalism has brought about significant growth in the country, and China has seen significant transitions towards market principles. Outside of promoting pure economic growth, China has been able to play a larger role internationally through participation in global organizations such as the World Trade Organization and the UN Security Council. In contrast, signs of reform in the DPRK have been minimal, and the country has maintained the highly totalitarian economic status quo for most of its history (Frank, 2OI2). Since the fall of the Soviet Union, the DPRK has become increasingly isolated and plagued by economic mismanagement, which has resulted in famine and shortages of basic supplies throughout the population. As China has sought to avoid a complete collapse of the regime, the Chinese government has filled the shoes as the regime's primary economic benefactor. China provides a substantial level of aid to the DPRK and accounts for the vast majority of its foreign trade. This relationship that China has found itself in is the source of another crack in the China-DPRK relationship, as it is not in China's national interest to maintain a relationship of complete dependency (Kim, 2OI7, pp. IIO-III).

The China-DPRK relationship, in its current form, is a complex and constantly-evolving geopolitical tangle of national interests. The DPRK has continued to develop its nuclear weapons program despite clear warnings against provocation from the international community. As the regime has sought to ensure its own survival through mutually-assured nuclear destruction, China has been forced into a situation in which it cannot allow the DPRK to destabilize the Asia-Pacific region in the event of a conflict. The DPRK's nuclear program is a significant threat to Beijing's primary goal of ensuring peace and stability on the Korean peninsula, as China's own economic development program depends on regional peace (Kim, 2OI7, pp. III). As the DPRK has continued to move forward with its nuclear weapons testing, Beijing has responded on multiple occasions by standing with the rest of the United Nations Security Council in approving a growing list of sanctions against the regime. Chinese approval of sanctions is a significant political development, especially since China had once characterized its relationship with the DPRK as "bonded in blood" (Ohn, 2OI5, pp. 484). This political evolution of China's foreign policy is a sign that Chinese leadership is losing its patience with the government in the DPRK, and may be rethinking the costs and benefits of maintaining support for the regime. This incredible departure from its once unbreakable bond with the DPRK can be explained as a product of the economic and political progress made in China since the I99Os. As China's economic model has shifted to state-sponsored capitalism, it has become a market for world trading partners. As Moore discusses, "China's economy is now heavily dependent on trade, and trade requires stability ... Most serious for China is the link between regional stability and trade, on the one hand, and China's domestic economic growth and political stability on the other" (Moore, 2007, pp. I7). It is imperative for Chinese leadership to ensure continued economic growth by ensuring lasting peace in Asia. At the core of this peace, in the eyes of China, lie two vital geopolitical goals: first, China aims 
to ensure that the Korean peninsula is fully denuclearized, a goal that the DPRK directly stands in the way of. Second, China views the DPRK's continued existence as a critical buffer between Chinese territory and American military installations (Moore, 2007, pp. I6). These two goals fundamentally oppose each other, representing the dilemma facing Chinese policymakers when it comes to the Korean Peninsula.

China's response to the significant dilemma around the DPRK has in large part consisted of a twopronged, duplicitous policy of both economic engagement and political pressure. Chinese economic engagement consists of a combination of large aid packages and smaller-level trade at the local level. Despite the significant strain on relations between the DPRK and China documented so far, there is little evidence that trade between the two states has seen a decline (Snyder, 20I4, pp. IO6). As Snyder reports, economic exchanges between Chinese businesses and the North Koreans have continued to show strong expansion at the local level, despite the increased sanctions brought about since 2013 (pp. Io6). Indeed, the Council for Foreign Relations estimates that total trade between the two countries totalled $\$ 2.6$ billion in 2016 , up IO percent from the previous year (Albert, 2OI7). Chinese trade with the DPRK is also somewhat diversified, as Chinese exports to the country consist of a combination of oil, machinery, manufactured goods, and food (Reilly, 20I4, pp. 926). On the surface this seems counterintuitive, given the fact that China has approved multiple UN Security Resolutions against the DPRK within that same time period. The Chinese government views economic relations with the North Koreans as crucial in preventing a complete collapse of the already severely impoverished and cash-strapped country. As the only significant source of outside trade to the DPRK, China is in a position in which it alone is responsible for preventing a potentially disastrous collapse of the North Korean economy. For China, the collapse of the regime in the DPRK would be a national security crisis, as it would likely result in the reunification of the peninsula under the control of the American-backed Republic of Korea. This would mean that American troops could essentially be stationed on the border with China, something that Chinese leaders have viewed as a geopolitical nightmare for much of the past half-century.

Despite the flourishing economic relationship between China and the DPRK, political relations remain chilled. China's core national interest of being the only nuclear power in its geopolitical narrative has become increasingly challenged by the ever-advancing DPRK's nuclear weapons program. Against China's wishes, the regime has continued to test nuclear weapons and has steadily improved the range and reliability of its intercontinental ballistic missile program. These provocations are especially concerning from a Chinese foreign policy standpoint, as continued testing in the face of international condemnation raises the risk that the Americans could escalate the conflict, which could force China's hand militarily. In response, China has participated in talks with all parties involved in the issue, and has on multiple occasions approved Security Council resolutions aimed at restricting the DPRK's ability to develop nuclear weapons. Min-Hyung Kim evaluates this changing narrative among Chinese leadership, explaining that continued North Korean provocations “undermine Beijing's new foreign policy goal of 'peaceful rise' [and] are driving China's changing strategic view on North Korea from a special relationship to a normal state-to-state relationship" (Kim, 2OI7, pp. IIO). This transition to a normal state-to-state relationship is significant, especially as the number of state visits by Chinese officials to the DPRK has decreased (Reilly, pp. 9I8). Despite this, the importance of the DPRK to China's wider foreign policy goals in East Asia should not be understated. In order to maintain growth levels and fulfill its ambitions to become a regional superpower, China requires the North Korean buffer to exist as a check on further US encroachment in the region. The way the Chinese government sees it, however, is that the continued testing of weapons and escalating 
provocations will serve to hasten the demise of the regime in the DPRK. The international community continues to grow impatient, and China risk losing international credibility as long as it continues to prop up the DPRK economically. For this reason, it is in China's best interests to find a peaceful resolution of the conflict, free of nuclear weapons, while maintaining the political status quo in the DPRK. China has a great deal to lose in the Korean crisis, as it has placed its own international credibility on the line. As China has increasingly sought international recognition as a world power through participation in international institutions, it has billed itself as a responsible stakeholder of the global political system. President Xi has spoken of a desire to be a leader on multiple world issues, and to restore China to what he sees as its rightful place in global affairs (Ohn, 20I5). As China has shown a clear desire to be a leader in a multipolar world, it will have to demonstrate to the global community that it can take a hard stance on the issue of nuclear weapons in the DPRK. Chinese President Xi Jinping has already demonstrated that Chinese relations with the DPRK are not what they once were, and has distanced himself from the North Korean leader. This can be concluded from the fact that President Xi met with former South Korean President Park Geun-Hye eight times between 2013 and 20I6, whereas he has never met North Korean leader Kim Jong-Un in person (Kim, 2OI7, pp. IIO). This distance that Xi has put between himself and the North Korean regime can be viewed from the outside as a way of demonstrating to the world that the days of China-DPRK relations being compared to "lips-and-teeth" are a thing of the past.

Despite the evidence explained above, there are competing views around the nature of ChinaDPRK relations. From the American perspective, many politicians and some political scientists charge China with backing the DPRK as a way of challenging US power in the Asia-Pacific region. As Moore argues, many Americans overestimate the level of influence that the Chinese government has on the DPRK (Moore, 2007, pp. 23). US President Donald Trump has, on multiple occasions, called upon China to "rein in" the regime's weapons program in exchange for better US-China relations (Holland, 2OI7). This view ignores the sensitivity of Chinese national security interests, and does not account for the interests of the government of the DPRK itself. Moore's examination of this flawed American perception of Chinese foreign policy demonstrates that any predictor of future Chinese action on the Korean peninsula needs to take into account the histories and interests of all relevant national actors. American policymakers cannot overestimate the pull that the Chinese government has on the government of the DPRK, as it risks overlooking the driving interests behind the regime's weapons program and will continue to produce antagonism between the US and China.

An analysis of all aspects of China's national interests on the Korean Peninsula is vital in gaining an understanding of the geopolitical reality around the Korean issue. As this paper discussed, Chinese interests in Korea have a long history, and China has been an important political actor on the peninsula for hundreds of years. The geographical location of the Korean Peninsula presents a serious security threat to the Chinese mainland should it come under the control of an adversary, and this fear is reflected clearly in Chinese foreign policy towards the DPRK. As the conflict over North Korean weapons testing continues to escalate, Chinese policy reflects a two-pronged approach to both economically stabilize the regime and hamper its ability to produce nuclear weapons. Chinese national interests are highly dependent on the stability of the region around China, and Chinese policymakers make it abundantly clear that stability is their primarily concern when dealing with the issue of the DPRK. China requires a stable DPRK as a guarantee against US encroachment on China's border, but recent provocations equate to an equally complex security challenge. As the regime's weapons program continues to threaten the stability of Asia, it 
can be expected that Chinese distance from DPRK leadership will continue to grow. As China continues to build an image of internationalism as a responsible stakeholder in the global system, it will increasingly need to take a stance that puts it at odds with the government in the DPRK. Despite this, it can be expected that Chinese policymakers will continue to provide economic aid and encourage trade and private investment in the DPRK. This economic relationship is vital to the stability of the regime in the DPRK, and the Chinese view economic ties as necessities in order to avoid that chaos and instability of a collapse of the DPRK. American policymakers will continue to argue that China has the ability to halt the DPRK's aggression, but it will remain in China's best interest to continue a carefully calculated policy of both economic engagement and political pressure. Maintaining the political status quo in the DPRK while pushing for denuclearisation is in China's national geopolitical interests, as it is the most effective way to protect stability in the Asia Pacific region.

\section{References}

Albert, Eleanor. (20I7, September 27). Understanding the China-North Korea Relationship. Council on Foreign Relations. Retrieved December 3, 2OI7, from https://www.cfr.org/backgrounder/china-north-korea-relationship. 
Chung, J. H., \& Choi, M. (2013). Uncertain allies or uncomfortable neighbors? Making sense of China-North Korea relations, 1949-2010. Pacific Review, $26(3)$, 243-264. DOI: 10.Io8o/09512748.2012.759262.

Frank, R. (20I2, October 2). An Atmosphere of Departure and Two Speeds, Korean Style: Where is North Korea Heading? Domestic Affairs, 38 North. US-Korea Institute at John Hopkins SAIS. Retrieved from http://www.38north.org/2OI2/IO/rfrankioO2I2/.

Holland, S. (2017, October 20). Trump expected to pressure China's Xi to rein in North Korea: officials. Reuters. Retrieved December 3, 20I7, from https://www.reuters.com/article/us-northkorea-missiles-trump-xi/trump-expected-to-pressurechinas-xi-to-rein-in-north-korea-officials-idUSKBNICP2SG.

Ji, Y. (200I). China and North Korea: A fragile relationship of strategic convenience. Journal of Contemporary China, $10(28)$, 387-398. DOI: 10.1080/1067056or20o6709o.

Kim, M.-h. (2017). Cracks in the blood-shared alliance? Explaining strained PRC-DPRK relations in the post-Cold War world. Pacific Focus, 32, I09-I28. DOI: I0.IIII/pafo.I2087.

Moore, G. J. (2007, October 8). How North Korea threatens China's interests: understanding Chinese 'duplicity' on the North Korean nuclear issue. International Relations of the Asia-Pacific, 8, I-29. DOI:Io.Io93/irap/lcmo23.

Ohn, D. \& Richey, M. (2015). China's evolving policy towards the Democratic People’s Republic of Korea under Xi Jinping. Asian Studies Review, 39(3), 483-502. DOI: I0.IO80/IO357823.2015.IO52778.

Reilly, J. (20I4, December). China's economic engagement with North Korea. China Quarterly, 220, 915-935. DOI:IO.IOI7/So3O574IOI4OOII43.

Snyder, S., \& See-won, B. (20I4). China-Korea Relations: China's Red Line on the Korean Peninsula. Comparative Connections: A Triannual E-Journal on East Asian Bilateral Relations, 16(I), IO3-II3. 